\title{
Literatures of Inculturation: Achebe, Jumbam and Adichie
}

\author{
André Kaboré ${ }^{1, *}$ \\ ${ }^{1}$ Department of Anglophone Studies, University of Ouagadougou, Ouagadougou, Burkina Faso \\ *Correspondence: Centre National Cardinal Paul Zoungrana, 01 BP 1195 Ouagadougou 01, Burkina Faso. E-mail: \\ kaboreandre@hotmail.com
}

Received: December 1, 2015 Accepted: February 19, 2016 Online Published: March 6, 2016

doi:10.5430/wjel.v6n1p1

URL: http://dx.doi.org/10.5430/wjel.v6n1p1

\begin{abstract}
Most African writers have been brought up as Christians. But some of them publicly rebelled against Christianity by dropping their Christian names: Chinua Achebe (formerly Albert C. Achebe), Kofi Awoonor of Ghana (formerly George Awoonor-Williams), Ama Ata Aidoo of Ghana (formerly Christiana Aidoo), Ngugi Wa Thiong'o of Kenya (formerly James Ngugi), and Okogbule Wonodi of Nigeria (formerly Glory Wonodi). The dropping of Christian names does not mean that their literatures discredit Christianity in favour of African traditional religions. This paper shows that against all expectations, most African writers who read Western Christian-oriented literature (Okere, 2009, p. 303) during their education, especially Chinua Achebe with Things fall apart, Kenjo Jumbam with The white man of God and Chimamanda Ngozi Adichie with Purple hibiscus tried to coin their own styles, mixing orality and literacy when they started their literary career, presenting in this way inculturation as an innovation in literary style and a solution to religious conflict. This paper focuses on the three novels by the three African writers in a comparative approach around suggested aspects of inculturation and shows the evolution of inculturation of Christianity as a novelty throughout these literatures.
\end{abstract}

Keywords: Achebe; Jumbam; Adichie; conflict; Christianity; African traditional religion; orality; inculturation

\section{Introduction}

It was assumed in the Victorian period that Western civilisation in union with Christianity would conquer the world. Nineteenth-century Victorian literature and culture carried out this idea throughout the twentieth century (Warren, 1965, pp. 58-67; Yates, 1994, pp.7-8). As a result, it is not surprising, as Okot p'Bitek reports, that "Western scholars have never been genuinely interested in African religions per se" (p'Bitek, 1970, p. viii). The reaction of African scholars was to defend African traditional religions, showing that African people knew the Christian God long before the missionaries' arrival in Africa. Mbiti's books, for example, show that "the African deities are but local names of the One God who is omniscient, omnipresent, omnipotent, transcendent and eternal" (p'Bitek, 1970, p. 47). African nationalists like Jomo Kenyatta, Leopold Sedar Senghor and John Mbiti had a similar mindset in defence of African traditional religions (p'Bitek, 1970, p. 41).

In literature specifically, African writers who address the theme of religion include Chinua Achebe in Things fall apart (1958) and Arrow of God (1964), T. M. Aluko in One man, one wife (1959), Onuora Nzekwu in Blade among the boys (1962), John Munonye in The only son (1966), Kenjo Jumbam in The white man of God (1980) and Chimamanda Ngozi Adichie in Purple hibiscus (2003), to name but a few. Did these writers and others imitate their European peers and ignore their ancestral religion, did they follow the nationalists in defence of it, or did they do something totally different from these two options? This paper focuses on three novels by Achebe, Jumbam and Adichie and argues in favour of the third possibility. It shows that, mixing orality and literacy and writing about two religions (Masks and Church) in different periods and contexts, while Achebe is mainly preoccupied with the ills in Igbo traditions that should be destroyed to allow it survive along with Christianity, Jumbam suggests the integration of traditional values in Christianity, and Adichie tackles issues arising within an inculturated Christianity. 


\section{Masks and Church}

Achebe's Things fall apart, Jumbam's The white man of God and Adichie's Purple hibiscus have two main points in common. First, they all deal with masks and churches. The masks represent African traditional religion, and churches, Christianity, brought in by European missionaries. There is a conflict as whether masks can find place within the Church or should the Church rather make tabula rasa of masks and all native cultural expressions. Masks within the Church, or outside it, or without it and vice versa - that is the question.

The debate between acculturation and integration is particularly contentious in all three books. In Things fall apart, the decision of Enoch, a fanatical convert, to strip one of the sacred egwugwu of its mask created conflict as the masked egwugwu responded by burning down the church. He and Mr Smith wanted the Church without masks. Mr Smith "condemned openly Mr Brown's policy of compromise and accommodation. He saw things as black and white. And black was evil" (Achebe, 1958, p. 130). Mr Smith's objective was acculturation, that is, replacing the Igbo culture by the British one.

In The White man of God, a missionary, Big Father, adopts a similar attitude toward masks. "Big Father kicked and kicked the Kibarankoh and when it turned round to him he pushed off its big mask and then got the shock of his life... He collapsed on the spot. The juju put on his mask and ran back" (Jumbam, 1980, p. 143). Big Father is thus punished for his misdeed. In Purple hibiscus too, there is a procession of masks to which Aunty Ifeoma takes her brother Eugene's children and Papa-Nnukwu. Such masquerades are, according to Eugene, 'Devilish Folklore' (Adichie, 2004, p. 85), and so Christians should not get involved. So Eugene militates for a Church without masks. However, Fr. Brown in Things fall apart, Matiu in The white man of God and Father Amadi in Purple hibiscus think of ways of integrating masks into Christianity. They are involved in the task of inculturation.

Inculturation is different from syncretism, which happens when people want to practice Roman Catholicism as a supplementary religion to their own traditional belief system and practices. Inculturation aims to bring the Christian religion into every aspect of life of the local communities and to be more accommodating and tolerant towards local practices and customs that do not stand in direct contradiction to Catholic doctrine. Pope John Paul II (1995, p. 60) defined it as 'the process by which 'catechism takes flesh in the various cultures.' Inculturation includes two dimensions: on the one hand, 'the intimate transformation of authentic cultural values through their integration in Christianity' and, on the other, 'the insertion of Christianity in the various human cultures'." Achebe's concern about the ills of Igbo social organisation with the advent of Christianity puts him partly in the first dimension in the definition, whereas the other two novelists' inculturation has to do with the second dimension.

Secondly, in each novel, there is a dichotomy between generations - children do not follow their parents' religion. In Things fall apart, Okonkwo, who is strongly attached to the ancestral traditions and who raised his child, Mwoye, to be like him, sadly realises that he has borne a Churchgoer, not a mask-bearer, when his son converts to Christianity. Likewise, in The white man of God, Tansa, who has been raised by a strong-willed pious Christian mother, is attracted to traditional religion to the extent of participating in a sacrifice. In Purple hibiscus too, Kambili and her brother Yaya are not as pious as their devout father Eugene; they listen to Aunty Ifeoma who brings them to see the masquerade. In each case, when the parents are attached to the mask and everything that revolves around it, their offspring reject it for the Church and vice versa. Yet, both parents and children have to form one family. Achebe, Jumbam and Adichie suggest inculturation as a means through which this family can be formed.

\section{Inculturation in Achebe's Things fall apart: purifying African masks of non-values}

The influence of both Christianity and Igbo traditional religion on Chinua Achebe testifies to the power of the extended family on an individual's life. In fact, Achebe was born to an extended family that had Christians and adherents of Igbo traditional religion in its midst. His father and mother were devout Christians and christened him Albert at birth and gave him "a rigid and guarded Christian upbringing" (Achebe, 1973, p. 67). Yet, his great grandfather, who allowed the earliest missionaries to settle near his compound and gave permission to Achebe's father to join them, still practised Igbo traditional religion, and so did Achebe's uncle and his family, refusing to be converted by Achebe's parents. Achebe was brought up in this religiously hybrid family as he describes himself: "We lived at the crossroads of cultures. On one arm of the cross we sang hymns and read the Bible night and day. On the other arm my father's brother and his family ... offered food to the idols" (Achebe, 1973, p. 67).

The influence of both religions on Achebe leads him to write about them. Reading his works one easily agrees with Okere $(2009$, p. 304) that "Christianity has so much hold on him that issues of the colonial missionary encounter dominate his first three novels." But of more importance is how Achebe, a nationalist writer, writes about 
Christianity. He said that he wrote his novels, "especially those set in the past," in view of correcting the distorted accounts of Africa given by European explorers, missionaries, administrators and writers (Achebe, 1975, p. 70). Judging from this assertion, one would expect a literature stylistically similar to Victorian literature replacing Europe and Christianity by Africa and its religions. Yet, it is a false expectation as Achebe develops his own style of writing.

In Things fall apart, his first novel, his preoccupation is a fair description of the encounter of two cultures: the Western and the Igbo. Without condemning or praising Christianity, his narrative is even critical of Igbo culture, including its religion, as his narrative highlights what is odd in this culture. He shows the shortcomings Igbo culture should get rid of if it wants to survive from the inevitable conflict of cultures. Achebe's purification of Igbo culture is not explicitly targeted toward its introduction into Christianity, which would have corresponded fully to the first dimension of inculturation, but as the process of purification is triggered by the presence of Christianity, and as integration presupposes co-existence, Achebe's focus on the odds in Igbo culture is an act of inculturation.

Achebe shows that the greatest default Igbo religion should abandon is the discrimination against the outcast or osu and the mothers of twins and their babies. Achebe's narrative makes it clear that the social mistreatment of the osu, like Enoch, and the mothers of twins, like Nneka, and their sympathizers, like Mwoye, led them to Christianity. Mwoye joined the missionaries because he was profoundly disturbed by these abominations and human killings: "It was not the mad logic of the Trinity that captivated [Nwoye]. He did not understand it. It was the poetry of the new religion, something felt in the marrow. The hymn about brothers who sat in darkness and in fear seemed to answer a vague and persistent question that haunted his young soul - the question of the twins crying in the bush and the question of Ikemefuna who was killed. He felt a relief within the hymn poured into his parched soul." (Achebe, 1958, p. 139)

To sacrifice human beings and throw away twins is to live in darkness and fear. Mwoye decides, and he sees himself as coming out of this darkness into the light of Christianity. His questions concerning the Igbo masculine code of behaviour, the killing of twins and the sacrifice of his beloved friend, Ikemefuna, which could not be answered within the traditional framework of Igbo culture, did find responses within Christianity. Christianity becomes the mirror through which Achebe presents the ills of Igbo society.

Achebe focuses on the shortcomings of Igbo culture because its survival lies on its capacity to mend them. In other words, Igbo culture was falling down even before the missionaries' arrival because of the discrimination against the $o s u$, twins' mothers, the practice of human sacrifice and the poor economic system that worsens the poverty. With these defects, it could not stand against any foreign system. The missionaries did not do much to make things fall apart. Their presence simply gave an option to those who did not find themselves well looked after in the Igbo culture.

Through Okonkwo's death, Achebe finishes his novel with the suggestion that it is better to practise any religion than none. Okonkwo refuses to convert to Christianity and is also unfaithful to Igbo traditional religion, as he violates its sacred laws by hanging himself. It appears that in a conflict of religions, one has the choice between tolerance, inculturation or death. In death, Okonkwo belongs to no religion. It is again the Christians who care for his corpse, which shows how the Igbo religion treats its members who once wholeheartedly fought for it. So, Achebe, in dramatising the contingent nature of the historical moment of encounter between the British and Igbo cultures and religions, wants the Igbo society to blame itself for its downfall. The inculturation-minded reader understands that the inculturation of Igbo culture into Christianity presupposes a change in traditional social norms and retrograde customs. Once this step is achieved, one can proceed to inculturation proper.

\section{Inculturation of Christianity in Jumbam's White man of God}

Jumbam's The white man of God similarly focuses upon the conflict of the old traditional religion against the new religion introduced by Christian missionaries. The religious situation is also similar in the countries of the two authors: Jumbam's Cameroon, like Achebe's Nigeria is a poly-religious country. Cameroon's and Nigeria's populations are composed of traditional religionists, Christians and Islamists. In both countries, traditional religions are progressively yielding to the influence of Christianity and Islam (Egudu, 1973, p. 15; Banadzem, 1996, pp. 125-139).

Furthermore, Jumbam drew inspiration from Achebe's novel. Like Achebe, Jumbam believes that Africans should get rid of outmoded customs and only keep what is life-enhancing in traditional customs. In both narratives, two types of missionaries using different evangelizing methods and approaches to Christian teaching take turns: Mr Smith and $\mathrm{Mr}$ Brown in Things fall apart, and Big Father, Small Father and Father Cosmas in The white man of God (and Father 
Benedict and Father Amadi in Purple hibiscus). The former respectively are rigid, but the latter are more flexible and try to understand the people they work with.

Parallel characters that represent two different worldviews, one modern, the other traditional, appear in all novels. For example, Okonkwo's bemoaning his fate for having a childlike Mwoye who converts to Christianity in Things fall apart finds a counterpart in The white man of God, in the Christian woman Lalav lamenting over her son Tansa who participates in a traditional rite while her mother, Yaya, approves of the pertinence of her grandchild's action. These contrastive characters testify to the balance regarding the handling of Christianity in these novels. In fact, unlike Beti's and Oyono's novels that say nothing good about Christianity, most critics agree that Jumbam's The white man of God, and Achebe's Things fall apart give an impartial presentation of the missionaries' position (Brown, 1987, p. 221; Okere, 2009, p. 303; Banadzem, 1996, p. 137).

Inculturation appears in the literary style of both writers as they integrate African storytelling techniques into Western typography. The two novels are thus stylistically similar. Both writers tried to differentiate themselves from Western literary styles. They do so by mixing oral and literary modes in their narratives. Abdul Janmohamed (2012, p. 578) has convincingly shown the sophisticated syncretism of oral and literate modes in Things fall apart, evidencing how "Chinua Achebe's style in Things fall apart is consonant with the oral culture that he represents", capturing the flavour of oral society with the use of parataxis, juxtaposition, addition, aggregation and periphrasis, thus making his style "a product of a double consciousness, of a syncretic combination of chirographic and oral techniques" (Janmohamed, 2012, p. 580). Likewise, Jumbam's narrative combines oral and literary modes. It is the author's feeling, as Ebot (1998, p. 47) puts it, that "in marrying the Western novel form to the African oral tradition, something new with its own distinctive identity will surely emerge." Orality is partly seen in the combination of comedy, farce, and tragedy, and in the fact that characters, like storytellers, painstakingly explain events to readers to ensure that they follow the story without effort, which makes Ebot $(1998$, p. 54) draw the conclusion that "the Africanisation of the novel in Jumbam's hands has resulted in the griotisation of the narrator." Both Jumbam and Achebe do not resort to Western delicacies such as aesthetic distance, self-conscious narration, and the like. Following Achebe in the combination of oral and literate modes, Jumbam and many other African writers show that the road towards a pure African novelistic expression, lies in literary inculturation, or as Stokle (1979, pp. 114-15) puts it "in the fusion of occidental and indigenous forms. And that fusion will be purely on Africa's terms."

One of the differences between the two novels is that Christianity is successful over traditional religion in Achebe's novel whereas in Jumbam's, traditional realism triumphs where Christian idealism fails. Instead of highlighting the self-destructive limitations of the traditional worldview, as Achebe does, Jumbam is preoccupied with showing the conflict of two religions in a way that suggests inculturation as a solution, or, as Ebot (1998, p. 44) puts it, "to synthesize a modern sense of identity from the European and African elements in their historical heritage." Jumbam wants Africans to enter into Christianity in a way that is similar to a literary innovation he carried out. In his other writing, he developed a style that enabled African children to have access to their traditional mythology, "taking African language children's verses and translating them carefully and lyrically into English, showing to children as no other Anglophone Cameroon poet is doing that English has music that is accessible to them, and is delivering to them in this mold their traditional mythology" (Arnold, 1983, p. 511). The white man of God appeals for a similar strategy to be used to facilitate entrance into Christianity. This process is part of inculturation.

In Things fall apart, the two categories of missionaries cared about getting more converts (Achebe, 1958, p. 130) and about acculturation, but in The white man of God one of them, Father Cosmas, shows concern for inculturation. Fr Cosmas is very kind and visits people, eats and drinks with them. He is praised for his love for people, especially children. He is "the favourite of the children. [...] Children talk about him every day." (Jumbam, 1980, p. 140). With children, he learnt Lamnso, the vernacular language, in a short period of time. Big Father, on the contrary, shows no interest in Lamnso. Father Cosmas begins speaking Lamnso just after having freshly arrived in Nkar. This is amazing to the native people: "And they all [exclaim], 'Imagine that! In the vernacular! And he has just come! Yes, and he has just arrived. Just arriving, not yet arrived even-?" (WMG, p. 106, Italics mine). The people want the missionaries to be interested in their culture of which language is an important part.

There are many other signs in the novel that evoke the idea of inculturation. As I have shown in my study on evangelisation in Jumbam's novel, "the inculturation in the Baptist Church and in Islam, as well as the comparison of values between the traditional and the Christian religions are the main signs that lead us to think about the necessity of inculturation as a sine qua non condition for a good evangelisation" (Kabore, 1999, p. 98). Inculturation is already implemented in the Baptist Church in the novel. The telling fact is the use of drums to worship God. This strikingly impressed Tansa when he went in the Baptist Church to witness the baptism of new Christians: "The tom-tom drum 
beat, and the Christians lined up behind the candidates and their god-parents, who in their turn lined up behind the band. It played sacred songs which the congregation sang at the same time as the drums beat. It was not customary at the time to have Catholic Christians beating drums in worship and praise of God. We had been made to understand that drums were instruments meant for diabolical use" (WMG, p. 99, Italics mine).

This comparison of the successful Baptist and the less thriving Catholic Church shows the advantage of the church that practises inculturation. Also, through the hybrid character of Mathew, the head catechist, Jumbam shows that the absence of inculturation leads people to develop a double or hypocritical life, being Christian in Church and traditionalist outside. Mathew's life is like a sheet on which Christianism is written on the front and traditional practices on the back. He is, as Ambanasom (2009, p. 52) puts it, "a classic hybrid, postcolonial subject in whom Roman Catholicism as a grand narrative fails to rewrite itself as a pure text. Mathew becomes a problematic figure of the third space, the hybrid subject caught within the in-betweeness that materializes between the first imperial space and the colonized narrative of the indigenous site. Hemmed in between these two hegemonies Mathew does not belong exclusively to any, but rather to both in a way that makes him less pure than the original occupants of the grand narrative of the imperial West, on the one hand, or the grand indigenous narrative of the village, on the other." This hybridity is a sign of the necessity of inculturation which is itself a form of hybridity. It will put an end to all forms of hypocrisy and illicit religious syncretism.

Even though Tansa fails to reconcile Christian and traditional practices in his own mind, readers of the narrative recognise the possibility of elaborating a viable African world view on the basis of Christian love and traditional values to favour the coexistence of both Christianity and the people of Nzo. Jumbam shows that Christianity can be meaningful to Nso people only if it relates to them in their daily lives. It can thrive and bear fruits in Nso only if it encounters the people where they are and not if it is imposed upon them from outside. Inculturation is a necessity for the survival of Christianity in any culture. But inculturation alone is not a sinecure. Even in an inculturated Christianity, people need to live in tolerance with other religions.

\section{Inculturated Christianity in Adichie's Purple hibiscus}

As in Achebe's Things fall apart and Jumbam's The white man of God, Adichie's Purple hibiscus is set in the past. Adichie drew her example from Achebe. She said that "reading Achebe gave [her] permission to write about [her] world. He transported [her] to a past that was both familiar and unfamiliar, a past [she] imagined [her] great grandfather lived" (Garner, 2004, p. 3). In Purple hibiscus, Adichie wanted to write the modern take of Things fall apart and Arrow of God (Garner, 2004, p. 4). The fear in Okonkwo's household finds a parallel in Papa Eugene's family. As Inyama (1998, p. 37) observes, "it would be difficult to imagine any of Okonkwo's children recalling childhood with affection or warmth, since the household is dominated by the fear of its ruler." Likewise, in Papa Eugene's family, children and their mother live in fear of the father and husband.

But chronologically speaking and in terms of the handling of the interaction between Christianity and African Traditional religion, Achebe belongs to the first generation of African writers, Jumbam to the second, and Adichie to the third. In fact, she focuses on Nigeria at a far more advanced stage of British colonisation than the moment of initial encounter that occupies Achebe and Jumbam. Christianity and missions are already deeply embedded within the traditional framework of Igbo culture when the novel opens.

In Purple hibiscus Adichie operates in a Christian environment. She is dealing with a situation in which Christians outnumber the adepts of traditional religion. Papa-Nnukwu is alone against his children and grandchildren. The focus is not so much about the missionaries than about Christians interacting daily with each other and with other non-Christians. Adichie's Purple hibiscus thus belongs to the third generation of literature that takes for granted Christianity as part of contemporary African culture. No attempt is made to recuperate traditional religion in everyday life. As Chennells (2009, p. 4) observes, Chimamanda Ngozi Adichie, "is the literary grandchild of Beti and Ngugi, and belongs to a generation for whom Christianity in its many manifestations is as much a part of African cultures as traditional religions are or perhaps were."

Inculturation that is strongly requested in The white man of God is already in operation in Purple hibiscus in different ways by all missionaries. Father Benedict, willing to preserve Latin as the language of the Catholic Church and also to inculturate Catholicism in Enugu, "changed things in the parish, such as insisting that the Credo and Kyrie be recited only in Latin... Also hand clapping was to be kept at a minimum, lest the solemnity of Mass be compromised. But he allowed offertory songs in Igbo; he called them native songs" (Adichie, 2004, p. 4). As to Fr. Amadi, "halfway through his sermon, he broke into an Igbo song: "Bunie ya enu..." (Adichie, 2004, p. 28) with the 
congregation slowly joining in. Also, Eugene Achike and his wife Beatrice, though they bear Western Christian first names, they give traditional names to their children: Yaya and Kambili. Such use of the Igbo language in the Catholic liturgy testifies to an inculturated Catholicism at work.

But inculturation is veering into syncretism. Papa Eugene is fighting against syncretism in favour of true inculturation that lies on the observance of only what was permitted by Rome. That is why he instructed his children on visit to their grandfather who has refused to become a Christian, not to eat anything there because their grandfather never eats without asking 'Ane, the god of the land, to eat with him' (Adichie, 2004, p. 65). Aunty Ifeoma's Catholicism veers into syncretism as, though morning and night prayers, and the rosary are held in her house, she allows her son, Obiora, to be initiated into the Igbo spirit world by participating in the ima mmuo rituals, a rite of passage that Eugene has refused to allow Jaja to undertake. She syncretises this initiation with the Catholic sacrament of confirmation as two equivalent rites of passage.

Eugene Achike is a complex character. He is not simply a fanatic or fundamentalist. Once he commits an act of fanaticism, his sorrow and regret call for extracting such act out of fanaticism. Each time he beats his wife or child, upon realising the damage he has caused, he drives the injured person into hospital. His objective is good but he uses the wrong means. Through this complex character, the pivot around whom the entire action of the novel revolves, Adichie shows the difficulty of achieving true inculturation. Syncretism is easier, as it allows everybody to take part in both religions. Inculturation demands selecting only the cultural values for integration within Christianity. What is not deemed of value by Christianity in any culture, such as the odd customs Achebe highlights in Things fall apart, cannot be incorporated into it. As cultures and traditions continue to be purified by Christianity, they can progressively be integrated at the appropriate time.

\section{Conclusion}

Inculturation is an unlimited process. The reader sees it dormant in Things fall apart, requested in The white man of God, applied and improvable in Purple hibiscus. Nowhere does the word "inculturation" appear in these novels. Yet, their authors know the reality of it and fight for it. They are involved in stylistic and religious inculturations. Stylistically, they integrate African storytelling artistic forms in Western typography. Religiously, Achebe focuses on the odd customs and social norms that cannot find a place in Christianity; Jumbam focuses on the success in the Baptist Church due to its implementation of inculturation and thus invites the Catholic Church to embark on the same road; and Adichie is preoccupied with issues arising within an inculturated Catholicism. Inculturation is an ongoing process in need of continual improvement and updating.

\section{References}

Achebe, C. (1978). An image of Africa. Research in African Literatures, 9(1), 1-15.

Achebe, C. (1975). Morning yet on creation day: Essays. London, England: Heinemann.

Achebe, C. (1973). Named for Victoria, queen of England. New Letters, 40(1), 17-18.

Achebe, C. (1958). Things fall apart. London, England: Penguin BooksAnchor Books.

Adichie, C. N. (2004). Purple hibiscus. London, England: Fourth Estates.

Ambanasom, S. A. (2009). The Cameroonian novel of English expression: An introduction. Bamenda, Cameroon: African Books Collective.

Arnold, S. (1983). Preface to a history of Cameroon literature in English. Research in African Literatures, 14(4), 498-515.

Bruner, D. K. (1981). The white man of God by Kenjo Jumbam, a review. World Literature Today, 55(4), 714-715. http://dx.doi.org/10.2307/40136497

Banadzem, J. L. (1996). Catholicism and Nso' Traditional Beliefs. In I. Fowler and D. Zeitlyn (Eds.), African crossroads: intersections between history and anthropology in Cameroon. (vol. 2, pp. 125-139). Oxford and Providence RI: Bergahn.

Brown, E. (1987). Reactions to western values as reflected in African novels. Phylon, 48(3), 216-228. http://dx.doi.org/10.2307/274382

Chennells, A. (2009). Inculturated Catholicisms in Chimamanda Adichie's Purple hibiscus. English Academy Review: 
Southern African Journal of English Studies, 26(1), 15-26. http://dx.doi.org/10.1080/10131750902768374

Ebot, W. A. (1997). Christianity and traditional reality in Kenjo Jumbam's The white man of God. Journal of Third World Studies, 14, 115-31.

Ebot, W. A. (1998). Language and action in Kenjo Jumbam's prose narratives. Research in African Literatures, 29(2), 43-56.

Egudu, R. (1973). Defence of Culture in the poetry of Christopher Okigbo. In E. D. Jones (Ed.), African Literature Today. (Vol. 6, pp. 14-25). London, England: Heinemann.

Garner, C. (2004). Profile of Chimamanda Ngozi Adichie. In C. N. Adichie, Purple hibiscus. (pp. 2-5). London, England: Fourth Estates.

Hopkins, R. F. (1966). Christianity and sociopolitical change in sub-saharan Africa. Social Forces, 44(4), 555-562. http://dx.doi.org/10.1093/sf/44.4.555

Inyama, N. F. (1998). 'Beloved pawns': the childhood experience in the novels of Chinua Achebe and Mongo Beti." In E. D. Jones, and M. Jones (Eds.), Childhood in African Literature. (pp. 36-43). Oxford: James Currey.

Janmohamed, A. On Chinua Achebe. Retrieved 01/12/2015 from http://engliteratureju.blogspot.com/2012/03/janmohamed-on-chinua-achebes-things.htmlLast

John Paul II. (1995). Ecclesia in Africa. Vatican City: Libreria editrice Vaticana.

Jumbam, K. (1980). The White man of God. London, England: Heinemann.

Kaboré, A. (1999). Evangelisation in Jumbam's writings. Mémoire de Maîtrise, Université de Ouagadougou, Burkina Faso: np.

Keim, C. A., \& Keim, K. R. (1982). Literary creativity in Anglophone Cameroon. Research in African Literatures, 13(2), 216-222.

Larson, C. R. (1972). The emergence of African fiction. (Revised edition). Bloomington and London, England: Indiana University Press.

Okere, A. C. (2009). Achebe and Christianity. In F. A. Irele (Ed.), Things fall apart: authoritative text, contexts and criticism. (pp. 303-322). New York, NY: Norton.

Ouma, C. E. W. (2009). Childhood(s) in Purple hibiscus. English Academy Review: Southern African Journal of English Studies, 26(2), 48-59. http://dx.doi.org/10.1080/10131750903336064

P'Bitek, O. (1970). African religions in western scholarship. Kampala, Uganda: East African Literature Bureau.

Stokle, N. (1979). Towards the africanisation of the novel: Francis Bebey's narrative technique. In K. Ogungbesan (Ed.), New West African Literature. (pp. 104-15). London, England: Heinemann.

Warren, M. (1965). The Missionary movement from Britain in modern history. London, England: SCM Press.

Yates, T. (1994). Christian mission in the twentieth century. Cambridge, England: Cambridge University Press. 